\title{
Video edukasi cara mencuci hidung yang benar sebagai salah satu upaya pencegahan Covid-19
}

\author{
Eka Arie Yuliyani1 ${ }^{*}$, Rika Hastuti Setyorini ${ }^{1}$, Eva Triani ${ }^{1}$, Indana Eva Ajmala1, Nurul Imaniaty As- \\ syarifiah2, Mochamad Fauzi Aulia Akbar ${ }^{2}$ \\ ${ }^{1}$ Departemen THT-KL, Fakultas Kedoteran, Universitas Mataram, Mataram, Indonesia. \\ ${ }^{2}$ Departemen Pulmonology, Fakultas Kedokteran, Universitas Mataram, Mataram, Indonesia \\ ${ }^{3}$ RS Universitas Mataram, Mataram, Indonesia.
}

DOI: https://doi.org/10.29303/indra.v2i2.123

\section{Article Info}

Received : 02-08-2021

Revised : 22-09-2021

Accepted: 22-09-2021

\begin{abstract}
The nasal epithelium and nasopharyngeal mucosa are the main entry points and sites of SARS-CoV-2 replication. Therefore, it is very important to be able to maintain the health of the nasal and oral cavities during this pandemic, namely by nasal washing with salt water and gargling. Nasal washing is a practical, simple, economical, and feasible method to be applied in everyday as well as a non-pharmacological therapy to clean the nasal cavity from various microorganisms including reducing the number of viruses in the nasal cavity, so education about this is considered important to do. Online education is the right choice during this pandemic because people do more work from home and information about various things, including information about health, can be accessed quickly. This is an opportunity for health workers to provide education to the community, one of which is through a nasal washing video where in this video we discuss knowledge about nasal washing, its benefits and especially how to do it properly. In addition, the public can also provide input about this educational video through the google form, so that it can be suggestions for improvements in the future.
\end{abstract}

Keywords: Nasal Washing, Educational video, Covid-19

Citation: Yuliyani, E.A., Setyorini, R.H, Triani, E., Ajmala, I.E., As-syarifiah, N.I., \& Akbar, M.F.A. (2021). Video edukasi cara mencuci hidung yang benar sebagai salah satu upaya pencegahan Covid-19. INDRA: Jurnal Pengabdian kepada Masyarakat, 2(2), 37 - 40. doi: https:// doi.org/10.29303/indra.v2i2.123

\section{Pendahuluan}

Pada era revolusi ilmu pengetahuan dan teknologi, perubahan masyarakat, pemahaman belajar, kemajuan media komunikasi dan informasi memberi arti tersendiri bagi kegiatan pendidikan. Tantangan tersebut menjadi salah satu dasar pentingnya pendekatan teknologi dalam pengelolaan pendidikan dan pembelajaran (Munadi, 2013). Informasi tentang berbagai hal dapat diakses dengan cepat termasuk informasi tentang kesehatan.

Video edukasi merupakan salah satu metode pembelajaran yang dinilai efektif untuk membantu proses pemahaman seseorang tentang sesuatu. Batubara \& Ariani (2016) menunjukkan bahwa keunggulan video sebagai media pembelajaran mudah digunakan dan mampu menjelaskan konten dengan lebih nyata. Hal inipun yang digunakan sebagai peluang oleh para tenaga kesehatan untuk memberikan edukasi kepada masyarakat (Kadriyan, 2019).

Di masa pandemi seperti sekarang ini video edukasi merupakan metode yang baik dan menjadi pilihan untuk menyampaikan pesan kesehatan kepada masyarakat, salah satunya adalah cuci hidung. Seperti yang telah disebutkan pada berbagai literatur, bahwa epitel hidung dan mukosa nasofaring merupakan pintu masuk utama dan lokasi untuk terjadinya replikasi SARS-CoV-2 (Prashant, 2020). Pada tanggal 30 Juni 2020 terdapat 216 negara di dunia yang sudah 
terkonfirmasi terkena Covid-19 dengan angka positif 10.117.687 dan meninggal 502.278. Di Indonesia, kasus positif berjumlah 56.385 , sembuh berjumlah 24.806 dan meninggal berjumlah 2.876 (COVID-19, 2020). Oleh karena itu, menjaga kebersihan rongga hidung dan mulut menjadi cara terbaik sebagai upaya pencegahan terhadap Covid-19 dengan cara mencuci hidung dengan larutan salin dan berkumur dengan air asin (Prashant, 2020).

Cuci hidung merupakan suatu metode praktis, sederhana, ekonomis, dan layak diterapkan dalam kehidupan sehari-hari. Pada beberapa penelitian yang telah dilakukan bahwa tindakan cuci hidung dengan larutan salin ini dapat ditoleransi dengan baik tanpa adanya efek samping yang menyakitkan dan dapat membantu memperbaiki kualitas hidup (Suh dan David, 2011). Larutan garam isotonis memiliki mekanisme kerja sebagai pembilas zat-zat iritan dan alergen yang berada di dalam rongga hidung dan dikatakan juga sebagai larutan yang paling fisiologis terhadap morfologi seluler epitel hidung sehingga aman dan nyaman digunakan oleh pasien (Heatley et al., 2011; Hendradewi et al., 2016).

Pada tahun 1931, Proetz pertama kali menjelaskan metode dan larutan cuci hidung dalam sebuah buku dan ditahun yang sama, ahli otolaringologi merekomendasikan cuci hidung untuk mengatasi nyeri kepala hingga saat ini cuci hidung digunakan untuk mengatasi berbagai keluhan sinonasal (Heatly, 2011). Cuci hidung dengan salin isotonis ini juga sering direkomendasikan sebagai terapi non farmakologi dalam upaya strategi pencegahan untuk membersihkan rongga hidung dari berbagai mikrooganisme seperti bakteri dan virus serta mediator inflamasi khususnya dalam hal kemampuannya yang dapat menurunkan jumlah virus di dalam rongga hidung (Casale, 2020). Selain itu garam yang terkandung dalam larutan salin isotonis dapat menyingkirkan mukus dengan menurunkan viskositas mukus, sehingga silia dapat bekerja lebih efisien untuk menyingkirkan alergen, bakteri, virus ataupun zat-zat iritan lainnya, sehingga hal tersebut akan berdampak pada perbaikan transpor mukosilia (Marhayati dan Irwan, 2010).

Berdasarkan hal ini lah sangat perlu dilakukan sosialisasi mengenai cuci hidung, manfaat dan cara melakukannya dengan benar sehingga masyarakat dapat memahami pentingnya cuci hidung serta mempraktekkannya dalam kehidupan sehari-hari, sebagai salah satu upaya menjaga kesehatan rongga hidung dan pencegahan terhadap infeksi virus penyebab Covid-19.

\section{Metode}

Video edukasi cuci hidung ini dibuat secara bersama-sama oleh Tim pengabdian dan Dokter muda yang kemudian dilakukan editing sehingga menghasilkan gambar yang baik dan dilengkapi dengan beberapa animasi di dalamnya. Video ini merupakan video pendek dengan durasi 5-6 menit yang dilengkapi dengan penjelasan melalui pesan verbal dan disisipkan pesan tulisan serta dikombinasikan dengan gambar animasi dan gambar alamiah sehingga masyarakat diharapkan dapat menerima informasi dengan baik setelah menontonnya.

Video edukasi ini berisikan penjelasan mengenai tindakan cuci hidung, tujuan dan manfaat tindakan cuci hidung kemudian dilanjutkan dengan demo cara melakukan cuci hidung yang benar. Selain itu dalam video juga dilengkapi dengan penjelasan mengenai alat dan bahan yang diperlukan untuk melakukan tindakan cuci hidung, sehingga akan mempermudahkan bagi masyarakat untuk dapat mempraktekannya.

Video edukasi ini disosialisasikan pada bulan juli-agustus 2021 kepada beberapa pasien dan Nakes di RS UNRAM dengan ketentuan berusia 18 tahun ke atas, kooperatif dan bersedia menonton serta mengisi google form sehingga berjumlah 30 orang. Video ini disebarkan melalui link google drive yang diberikan oleh tim pengabdian kepada 30 orang tersebut dan sekaligus mengisi kuesioner melalui google form, dimana hasil survey tersebut digunakan untuk memantau umpan balik penonton.

Kuesioner tersebut berisikan beberapa pertanyaan sederhana berkaitan dengan pengetahuan dan kebermanfaatan video edukasi bagi penonton setelah menyaksikan video edukasi cuci hidung. Jawaban umpan balik dari peserta tersebut dapat dianalisis secara deskriptif untuk mengetahui gambaran pengetahuan dan kebermanfaatan video edukasi tersebut setelah responden menonton video, sehingga dapat digunakan sebagai bahan evaluasi terhadap pengembangan video edukasi di masa yang akan datang.

\section{Hasil dan Pembahasan}

Video edukasi cuci hidung ini dibuat dan disosialisasikan oleh Tim pengabdian masyarakat FK Unram dengan maksud agar masyarakat dapat mengetahui dan menyadari tentang pentingnya tindakan cuci hidung. Pada masa pandemi Covid-19 ini, berbagai upaya telah dilakukan pemerintah guna memutus rantai penyebarannya. Mulai dari penyebaran informasi melalui berita, majalah, hingga sosial media agar masyarakat senantiasa mematuhi prokes dan selalu menjaga kesehatan. Termasuk salah satunya adalah kesehatan dan kebersihan rongga 
hidung dan mulut yang merupakan pintu masuk utama virus covid-19 (Casale et al., 2020).

Video edukasi cuci hidung ini diharapkan dapat menjadi salah satu media yang dapat diakses dan dipilih oleh masyarakat untuk memperoleh pengetahuan mengenai cuci hidung, manfaatnya serta cara melakukan tindakan tersebut dengan benar. Dengan tampilannya serta penjelasan yang diberikan secara audio visual diharapkan masyarakat mampu memahami dan mempraktekan tindakan cuci hidung dengan benar. Berdasarkan beberapa penelitian didapatkan bahwa setiap informasi yang diberikan kepada responden melalui media dengan menggunakan audio visual atau video, akan dapat dimengerti dengan baik karena setiap responden akan mudah mencermati jika terdapat gambar yang dapat dilihat dan suara yang dapat didengar. Video merupakan alat bantu atau media edukasi yang dapat menunjukkan kembali gerakan-gerakan, pesan-pesan dengan menggunakan efek tertentu sehingga dapat memperkokoh proses pembelajaran dan dapat menarik perhatian penonton (Notoatmojo, 2012; Melina, et al., 2014; Fadhilla, 2014).

Sama halnya dengan video edukasi cuci hidung ini menggunakan gabungan gambar alamiah dan animasi serta beberapa sisipan tulisan untuk melengkapi sehingga dapat membantu masyarakat lebih mudah memahami pesan yang disampaikan. Video edukasi dapat dilihat melalui link google drive yaitu

https://drive.google.com/file/d/1guEnLBmA_SmasB 8QS4f-R6VMA2PtdByd/view?usp=sharing

Berikut adalah cuplikan gambar pada video edukasi seperti yang terlihat pada Gambar 1.

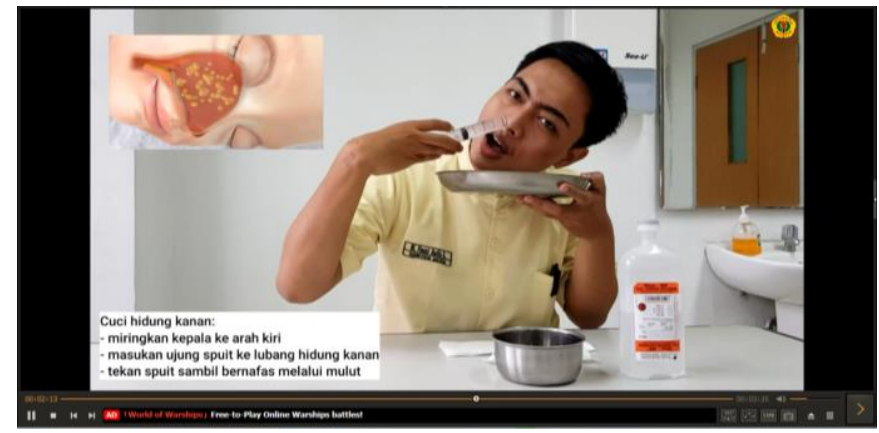

Gambar 1. Tampilan cuplikan pada video edukasi cuci hidung

Selain menonton video, masyarakat juga dapat melakukan umpan balik terhadap video tersebut dengan menjawab pertanyaan yang tertera pada kuesioner dan dikemas dalam google form yaitu melalui link : https://forms.gle/vRgZ2rnSzxZ76okF7 seperti yang ditampilkan pada Gambar 2, dimana setiap jawaban yang diberikan oleh responden dikumpulkan dan dapat dianalisis secara deskriptif guna evaluasi pengembangan video di masa yang akan datang.

Berdasarkan survey dari jawaban pertanyaan yang diberikan kepada 30 responden didapatkan data deskriptif bahwa setelah menonton video, pemahaman responden terhadap isi pesan yang disampaikan di dalam video edukasi sekitar 93\% dan kebermanfaatan video edukasi sekitar 93,33\%. Data ini menggambarkan bahwa video edukasi cuci hidung ini dapat diterima dengan baik oleh responden sebagai media edukasi dan dapat dikembangkan lebih baik lagi sehingga nilai kebermanfaatan dan pengetahuan yang disampaikan di dalam video semakin baik.

Menurut Igiany, et al. (2016), bahwa pemberian informasi melalui video dianggap efisien dan praktis. Selain itu video lebih bersifat mudah dipahami dan bisa di tayangankan berulang kali sehingga efektif untuk mengubah pandangan sasaran yang akan diintervensi. Menurut Sarkadi dan Syifa (2020), bahwa konten video edukasi yang berisikan materi tentang Covid-19 ini dinilai efektif, mudah dipahami dan penting untuk mengedukasi masyarakat dalam mendukung pemerintah menghadapi Covid-19.

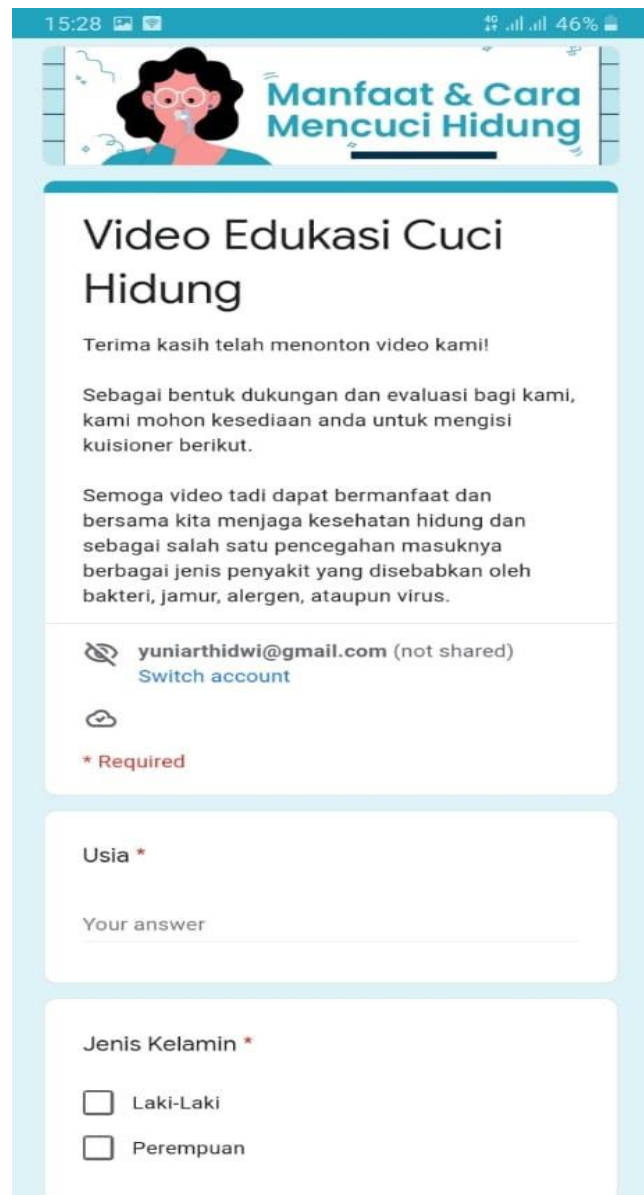

Gambar 2. Tampilan kuesioner dalam google form 


\section{Simpulan}

Kegiatan pengabdian berupa sosialisasi video edukasi tentang cuci hidung ini dapat diterima dengan baik oleh masyarakat. Video edukasi ini dinilai dapat memberikan pengetahuan serta manfaat dan termasuk teknik untuk melakukan cuci hidung yang benar kepada masyarakat, sebagai salah satu upaya pencegahan dengan menjaga kebersihan rongga hidung dari infeksi berbagai macam allergen, bakteri, virus atau zat iritan lainnya yang dapat menimbulkan penyakit.

\section{Ucapan Terima Kasih}

Penulis mengucapkan terima kasih kepada para peserta pengabdian dalam hal ini pasien dan nakes di RS UNRAM serta Bagian THT-KL RS UNRAM yang telah memberikan ijin dan dukungan pada kegiatan pengabdian ini. Terima kasih kepada Lembaga Penelitian dan Pengabdian Kepada Mayarakat (LPPM) Universitas Mataram yang telah memberikan dukungan financial terhadap pengabdian ini. Terima kasih pula kepada Teman Sejawat, Dokter Muda serta seluruh pihak yang telah membantu dalam pelaksanaan kegiatan pengabdian ini.

\section{Daftar Pustaka}

Batubara, H. H., \& Ariani, D. N. (2016). Pemanfaatan Video sebagai Media Pembelajaran Matematika SD/MI. Muallimuna Jurnal Madrasah Ibtidaiyah, 2(1), 47-66.

Casale, M., Vittorio ,R., Lorenzo, S., Antonio, M., \& Massimo, C. (2020). Could nasal irrigation an oral rinse reduce the risk for COVID-19 infection?. International Journal of Immunopathology and Pharmacology, 34, 1-3. https://doi.org/10.1177/2058738420941757

COVID-19, G. T. P. P. (2020). Website Gugus Tugas Percepatan Penanganan COVID-19. Retrieved August 3, 2021 from https:// covid19.go.id/

Fadhilla, H. N. (2014). Pengaruh Penyuluhan Cuci Tangan menggunakan Media Video terhadap Keterampilan Cuci Tangan pada Siswa Sekolah Dasar (Unpublished master thesis). Universitas Sebelas Maret, Surakarta, Indonesia.

Heatley, D. G. (2011). The Safety and Efficacy of Nasal Saline Irrigation. Madison: The Otolaryngology-Head and Neck Surgery University of Wincosin School of Medicine.
Hendradewi, S., Novi, P., \& Nurmala, S. (2016). Perbedaan transport mukosiliar pada pemberian larutan garam hipertonik dan isotonik penderita rinosinusitis kronis. ORLI, 46(2), 121-8. https://doi.org/10.32637/orli.v46i2.159

Igiany, P. D., Sudargo, T., \& Widyatama, R. (2016). Efektivitas penggunaan video dan buku bergambar dalam meningkatkan pengetahuan, sikap, dan keterampilan ibu mencuci tangan memakai sabun. Berita Kedokteran Masyarakat, 32(3), 89-94. http://dx.doi.org/10.22146/bkm.6196

Kadriyan, H. (2019). Pelayanan kesehatan Telinga Hidung Tenggorok Kepala dan Leher pada Masa Revolusi Industri 4.0: Refleksi dan Studi Kasus di NTB (1st ed.). Mataram: Mataram University Press. Retrieve from eprints.unram.ac.id

Maharyati, R., \& Irwan, K. (2010). Peranan Irigasi Larutan Garam Pada Rinosinusitis Kronis. (Unpublished master thesis). Bagian/SMF Ilmu Kesehatan THT Fakultas Kedokteran Universitas Airlangga/RSUD Dr. Soetomo Surabaya, Surabaya, Indonesia.

Melina F., Soebiyanto A. A., \& Wujuso, H. (2014). Perbedaan Media Pembelajaran ( Leaflet Dan Video ) Terhadap Keterampilan Sadari Ditinjau Dari Motivasi. J Kesehat "Samodra Ilmu," 05(02), 116-125.

Munadi, Y. (2013). Media Pembelajaran Sebuah Pendekatan Baru. Jakarta: GP

Notoatmodjo, S. (2012). Promosi Kesehatan dan Perilaku Kesehatan. Jakarta: Rhineka Cipta.

Prashanth, P., Kiranam,C., \& Archana A. (2020). Do saline water gargling and nasal irrigation confer protection against COVID-19?. Elsevier, 1-3. https://doi.org/10.1016/j.explore.2020.09.010

Sarkadi, \& Syifa, S. (2020). Video Edukasi Covid-19 Bagi Masyarakat Untuk Meningkatkan Tanggung Jawab Warga Negara yang Baik. Jurnal Ilmiah Pengembangan dan Penerapan IPTEKS, 18(2), 238-247. https://10.33369/dr.v18i2.13880

Suh, J. D., \& David, W. K. (2011). Treatment Option for Chronic Rhinosinusitis. Proceedings of The American Thoracic Society, 8, 132-40. https://10.1513/pats.201003-028RN 